\title{
USE OF SOYBEAN GENETIC RESOURCES TO CREATE HIGHLY ADAPTIVE VARIETIES
}

\author{
Viacheslav Sichkar $^{1}$, Volodymyr Orekhivskyi ${ }^{2}$, Lyudmila Bilyavskaya $^{3}$, Anna Kryvenko ${ }^{1 *}$, \\ Ruslan Solomonov ${ }^{1}$, Anna Diyanova ${ }^{3}$ \\ ${ }^{1 *}$ Odessa State Agricultural Research Station of NAAS, Ukraine; \\ ${ }^{2}$ Institute of Plant Physiology and Genetics of NASU, Ukraine; \\ ${ }^{3}$ Poltava State Agrarian University of MES of Ukraine, Ukraine; \\ "Corresponding Author Anna Kryvenko, e-mail: kryvenko35@ukr.net;
}

Received October 2021; Accepted November 2021; Published January 2022;

DOI: https://doi.org/10.31407/ijees12.106

\begin{abstract}
The scientific work highlights the importance of legumes in the agricultural sector of the world and Ukraine. The role of soybeans as an important protein crop in solving the world's food problem is shown. The narrow genetic base of existing soybean varieties requires the involvement of new source material in hybridization, especially one that has high adaptive properties. The study of a large volume of collection material over many years, numbering more than 6,000 samples, has identified donors and sources of such economically valuable traits as precocity, increased productivity, drought resistance, high attachment of lower beans, increased protein and fat content in seeds. It was found that ultra-early accessions of soybeans originate mainly from Sweden, Canada, Poland, Germany, and the Far East of Russia. Late-maturing genotypes are concentrated in the United States, Argentina, Brazil, Japan, India, Korea, Morocco, Australia, and Colombia. Such varieties as Arcadia Odeska, Khersonska 2, Prikos №5, Swift, Hodgeson, Evans are distinguished by high adaptive potential in the conditions of the South of Ukraine. Increased soybean yield is not due to one economically valuable feature, but the optimal combination of a number of indicators. High combination ability is characterized by soybean varieties from the USA Amsoy 71, Beeson, Corsoy, Evans, Swift, Harrison, as well as domestic origin - VNIIMK 9186, Kirovogradskaya 4, Belosneshka, Peremoga, Arcadia Odeska, Iskra. At the present stage to hybridization is necessary to involve new varieties Amethyst, Krasa Podillya, Alma, and Anthracite. The data of general and specific combination ability which need to be considered in breeding work are resulted. Highly adaptive varieties of soybeans have an increased growth rate in the initial stages of development, deeply penetrating into the soil root system, able to use moisture from deeper horizons. At the beginning of the growing season, the leaf surface of such genotypes grows rapidly before flowering, and then remains at the same level. They are characterized by small, upright leaves, especially in the upper and middle parts of the bush, which promotes better penetration of light into the lower sections of the canopy. In the process of research in the period 1979-2020, 36 soybean varieties were created, which are entered in the state register and recommended for cultivation in all areas of Ukraine.
\end{abstract}

Keywords: soybean, vegetation period duration, adaptability, collection samples, yield, protein content, economically valuable traits, new varieties, general and specific combination ability. 